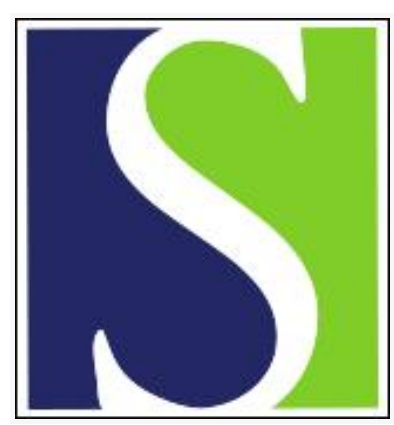

Scand J Work Environ Health 1992;18(2):85-89

https://doi.org/10.5271/sjweh.1597

Issue date: 01 Apr 1992

Cluster of brain cancers spuriously suggesting occupational risk among glassworkers.

by Wingren $\mathrm{G}$, Axelson $\mathrm{O}$

Affiliation: Department of Occupational Medicine, University Hospital, Linkoping, Sweden.

This article in PubMed: www.ncbi.nlm.nih.gov/pubmed/1604277

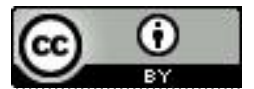




\title{
Cluster of brain cancers spuriously suggesting occupational risk among glassworkers
}

\author{
by Gun Wingren, BSc, Olav Axelson, MD, ${ }^{1}$
}

\begin{abstract}
WINGREN G, AXELSON O. Cluster of brain cancers spuriously suggesting occupational risk among glassworkers. Scand J Work Environ Health 1992;18:85-9. Indications of an increased risk of brain cancer in some, but not all, epidemiologic studies on glassworkers inspired further investigations in a geographically restricted region where the Swedish glass industry is located. Only a small and insignificant excess of brain cancer death was found among glassworkers when compared with the rest of the population in the area. However, when the brain cancer mortality of the glassworkers was compared with that of the whole Swedish population, a rather high risk was found, but an equally high risk was also seen for the rest of the population in this region when compared with national figures. Besides glassworkers, especially farmers, but also other occupational groups had an increased risk of brain cancer that suggested the possibility of an environmental factor affecting the whole population in the region. Hence particular worker groups may sometimes take on a regional mortality pattern that simulates an occupational risk.
\end{abstract}

Key terms: cancer, epidemiologic studies, farmers, occupational groups, register linkage.

Two studies based on the Swedish Cancer-Environment Register have shown an increased occurrence of intracranial gliomas [standardized incidence ratio (SIR) 1.7] and meningiomas (SIR 5.2) among glassmakers $(1,2)$. This register links cancer incidence for the years 1961 to 1979 with census information on employment in 1960 . Another Swedish study using the same register for only the years 1961 to 1973 showed an increased risk of brain tumors (SIR 2.4) among glassmakers irrespective of histological type (3). In a case-referent study based on death certificates a similarly increased risk (age-adjusted odds ratio 3.0) was also reported for white male workers in the glass manufacturing industry in the state of Illinois in the United States (4). However, other epidemiologic studies of this category of workers [ie, cohort studies from Sweden (5), Italy (6), and Finland (7) and two Swedish case-referent studies $(8,9)]$ found no excess risk of brain tumors.

The Swedish art glass industry is almost entirely located in a rather narrow area in the southeast part of the country. Except for the glass manufacturing there is no heavy or polluting industry. The glass industry handles several potential carcinogens such as arsenic, asbestos, nickel, cadmium, and chromium, but some other heavy metals are also included from time to time in the production, especially lead, as a major component in crystal glass. These metals, as well as other chemicals, have been discharged into the air and water for many years and have caused contamination of the ground, water, and plants in the surroundings

\footnotetext{
I Department of Occupational Medicine, University Hospital, Linköping, Sweden.
}

Reprint requests to: Ms G Wingren, Department of Occupational Medicine, University Hospital, S-581 85 Linköping, Sweden. of the glassworks (Kalmar County Administration and the health authorities of Nybro, unpublished data). Possible adverse health effects from these chemicals may therefore not only affect the glassworkers, but possibly also the population living close to the glassworks.

In view of the discrepant results of earlier studies with regard to brain cancer, this new study was designed so as to take into account more effectively the possibility that some environmental risk factor might have affected the total population in the region, rather than just the glassworkers. Material from a previous case-referent study on Swedish glassworkers could be further utilized for this purpose.

\section{Subjects and methods}

The local register of deaths and burials in 11 parishes with glassworks as the dominating industry were used as the source of subjects. Men only, deceased during the period 1950-1982, were included in the study. The exposure information was also obtained from the same register in terms of a job title. Most of the analyses were restricted to ages of $\geq 45$ years at the time of death (ie, cancer productive ages), but data on men deceased at younger ages were included in one of the analyses to account for the fact that brain tumors appear also in relatively young persons.

The causes of death were classified according to the eighth revision of the International Classification of Diseases (ICD-8), and the cases were selected as those persons who died of malignant tumors of the brain and nervous system (ICD-8 191-192). Case-referent analyses, stratified by age, were performed to evaluate the brain cancer risk among glassworkers as compared 
with that of the rest of the population covered by the local register, and with that of the total Swedish population as well (10). The case-referent design was adopted in favor of a proportional mortality ratio (PMR) design because previous studies $(8,9)$ had shown some malignancies and cardiovascular diseases to be associated with employment in glassworks. In a PMR study, these disease entities would therefore have affected the denominator of the exposed and would have biased the risk estimate. Instead, the casereferent design permitted some refinement by excluding malignancies and cardiovascular diseases from the reference group.

The age-standardized brain cancer risk for the total population in each of the 11 parishes was compared with that of the whole of Sweden through the calculation of the standardized risk ratio (SRR) with the Swedish population as the standard (11). In this way mutually comparable but somewhat unstable risk estimates, as based on small numbers in some strata, were achieved. The same calculations were also performed with data for all of the deceased men (ie, including those who had died before the age of 45 years).

To account for the possibility of some factor with a particular geographic distribution within the area,

Table 1. Case-referent data on the deceased men, 45 years of age or more, from 11 parishes in the glass-producing area of Sweden in 1950-1982. The cases of brain cancer (International Classification of Diseases, eighth revision 191-192) are compared with referents deceased from nonmalignant and noncardiovascular disorders. In the first comparison (A) the glassworkers were regarded as exposed and the others in the area ("Others") as unexposed, whereas in the second comparison (B) both glassworkers and the others in the area were regarded as exposed and the Swedish population formed the unexposed reference group.

\begin{tabular}{|c|c|c|c|}
\hline Age group & $\begin{array}{l}\text { Swedish } \\
\text { population }\end{array}$ & Glassworkers & "Others" \\
\hline \multicolumn{4}{|l|}{$45-64$ years } \\
\hline $\begin{array}{l}\text { Cases } \\
\text { Referents }\end{array}$ & $\begin{array}{r}3075 \\
129541\end{array}$ & $\begin{array}{r}9 \\
82\end{array}$ & $\begin{array}{r}20 \\
299\end{array}$ \\
\hline \multicolumn{4}{|l|}{$65-74$ years } \\
\hline $\begin{array}{l}\text { Cases } \\
\text { Referents }\end{array}$ & $\begin{array}{r}1389 \\
149423\end{array}$ & $\begin{array}{r}2 \\
88\end{array}$ & $\begin{array}{r}11 \\
435\end{array}$ \\
\hline \multicolumn{4}{|l|}{$\geq 75$ years } \\
\hline $\begin{array}{l}\text { Cases } \\
\text { Referents }\end{array}$ & $\begin{array}{r}459 \\
286892\end{array}$ & $\overline{169}$ & $\begin{array}{r}5 \\
1259\end{array}$ \\
\hline \multicolumn{4}{|l|}{ Total } \\
\hline $\begin{array}{l}\text { Cases } \\
\text { Referents }\end{array}$ & $\begin{array}{r}4923 \\
566056\end{array}$ & $\begin{array}{r}11 \\
339\end{array}$ & $\begin{array}{r}36 \\
1993\end{array}$ \\
\hline $\begin{array}{l}\text { A } \\
\text { Mantel-Haenzsel } \\
\text { odds ratio } \\
95 \% \text { confidence } \\
\text { interval }\end{array}$ & & $\begin{array}{c}1.3 \\
0.6-2.6\end{array}$ & 1.0 \\
\hline $\begin{array}{l}\text { B } \\
\text { Standardized } \\
\text { rate ratio }\end{array}$ & 1.0 & 3.6 & 2.8 \\
\hline $\begin{array}{l}\text { Mantel-Haenzsel } \\
\text { odds ratio } \\
95 \% \text { confidence } \\
\text { interval }\end{array}$ & 1.0 & $\begin{array}{c}3.6 \\
2.0-6.5\end{array}$ & $\begin{array}{c}2.7 \\
2.0-3.8\end{array}$ \\
\hline
\end{tabular}

we matched the men who had died of brain cancer in the four parishes with the highest risks with two referents of the same age \pm 5 years who had died of any kind of nonmalignant cause and who appeared in the register positions closest before and after the case. The addresses registered for the cases and their referents were checked with regard to geographic distribution and related to existing surveys of some heavy metals (ie, lead, arsenic, zinc, copper, cadmium, and mercury) in stream plants (geological survey of Sweden, unpublished data). Age-stratified case-referent evaluations were also performed, including only subjects from these four parishes, to evaluate the brain cancer risk among both glassworkers and other occupational categories in this part of the glass-producing area as compared with that of the Swedish population.

The statistical analyses in this study provide odds ratios (M-H OR) and $95 \%$ confidence intervals and followed the principles of Mantel-Haenszel (12) and Miettinen (13). SRR values with $95 \%$ confidence intervals were calculated as described by Rothman (14).

\section{Results}

The age-stratified estimate of the brain cancer risk for male glassworkers, with other men in the area as the reference, showed only a small and insignificantly increased risk for this occupational group. However, when the mortality from brain tumors in the same group of glassworkers was compared with that of the general population of Sweden, a much higher risk appeared. The same comparison for brain cancer mortality in the nonglassworking population in the region resulted in an almost equally high risk (table 1 ).

With the use of direct standardization, the brain cancer risk (SRR) is presented in table 2 for each of the 11 parishes included in the study, the Swedish population being used as the standard. Rather high estimates were found, particularly for the four geographically adjacent parishes (I, II, III and VI in figure 1 in the Discussion) in the eastern part of the glass-producing region. Sixty percent of the brain cancer deaths registered for the total area was found in these four parishes (table 2).

A separate analysis was performed on brain cancer mortality among the men of all ages from these four parishes (ie, also including men younger than 45 years of age at time of death). This evaluation only slightly changed the estimates and resulted in somewhat lower SRR values for three of the parishes (I-III) and a somewhat higher SRR for one (VI) (data not shown in table). The geographic distribution of the addresses for the cases and the age-matched referents within these four parishes showed no clear difference in pattern, however.

The case-referent evaluations by occupational group from the four "high risk" parishes showed increased brain cancer risk not only for the glassworkers, but also the other large occupational group in the region, 
farmers, had an even higher risk than the glassworkers. The remaining part of the population, not employed in glassworks or farming, also had a significantly increased risk, and therefore the excess of brain cancer was less likely to be primarily related to any occupation (table 3 ).

\section{Discussion}

Industrial and chemical exposures reported to be associated with an increased risk of brain cancer involve organic solvents, lubricating oils, acrylonitrile, vinyl chloride, formaldehyde, polycyclic aromatic hydrocarbons, and phenolic compounds (15). None of these chemicals are predominant or characteristic of the glass industry, however. Occupations that have been reported as associated with increased risks are dentists (16), chemists (17), and electricians and workers exposed to electromagnetic fields $(18,19)$, but also artists, teachers and physicians (15). An excess risk has also been reported for farmers $(20-22)$, and this risk has been especially related to the use of insecticides and fungicides (23). These chemicals, used in farming, can possibly also be an environmental risk factor for persons other than farmers. Living in the vicinity of a farm has been found to be associated with an increased risk for astrocytomas (24), and a higher than expected mortality has been reported for rural farm residents in the state of Minnesota in the United States (25). An interesting association has been reported between exposure to $\mathrm{N}$-nitroso compounds and brain tumors both in animal experiments (26) and in an epidemiologic study of children (27).

Of the various products used in glassworks, asbestos has been mentioned in connection with an excess mortality of brain tumors among insulation workers in the United States and Canada (28) although the mechanism is far from clear in this respect. It is nevertheless somewhat interesting that many of the cancer risks that have been found among glassworkers [ie, cancer of the lung, stomach, colon, larynx, and pharynx (5-9)] have also been found among insulation workers. Zinc and lead (as lead subacetate), which are metals used in the production of glass, have been found to influence the development of neoplasms in the brain in animal experiments $(28,30)$.

Data on the emission of chemicals, available especially for one big Swedish glassworks, show that large amounts of lead and arsenic, but also other metals, as well as sulfuric acid and hydrofluoric acid, have been discharged during the years of glass production. Environmental measurements performed in the $1970 \mathrm{~s}$ around this glassworks showed that the stream receiving the effluents of the glassworks had a low $\mathrm{pH}$ and that the concentrations of metals, especially of lead, were increased in the soil, water, and even in cultured vegetables in the closest surroundings (measurements performed under the supervision of the Kalmar
Table 2. Direct age-standardized rate ratios (SRR) and $95 \%$ confidence intervals $(95 \% \mathrm{Cl})$ for the deceased men, 45 years of age or more, from 11 glass-producing parishes $(I-X I)$ of Sweden in $1950-1982$, as compared with the general population of Sweden. (ICD-8 = International Classification of Diseases, eighth revision)

\begin{tabular}{lccc}
\hline Parish & $\begin{array}{c}\text { Brain cancer cases }(N) \\
\text { (ICD-8 }\end{array}$ & SR1-192) & SRa \\
\hline I & 7 & 4.4 & $95 \% \mathrm{CI}$ \\
II & 9 & 3.2 & $2.1-9.1$ \\
III & 6 & 2.4 & $1.7-6.1$ \\
IV & 4 & 2.3 & $0.9-6.1$ \\
V & 3 & 1.2 & $0.9-6.1$ \\
VI & 7 & 2.5 & $0.4-3.7$ \\
VII & 2 & 1.4 & $1.2-5.2$ \\
VIII & 2 & 1.6 & $0.3-5.6$ \\
IX & 2 & 1.2 & $0.4-6.4$ \\
X & 2 & 1.0 & $0.3-4.1$ \\
XI & 3 & 2.1 & $0.2-4.1$ \\
\hline Total & 47 & 2.2 & $0.7-6.5$ \\
\hline
\end{tabular}

a The mean of the Swedish population in the years 1960,1965 , and 1970 , and 1975 is the standard.

Table 3. Case-referent data on the deceased men, 45 years of age or more, from the "high risk" parishes (I, II, III and VI) of Sweden in 1950-1982. The cases of brain cancer (International Classification of Diseases, eighth revision 191-192) compared with referents deceased from nonmalignant and noncardiovascular disorders. Glassworkers, farmers, and others were regarded as exposed and the Swedish population as unexposed.

\begin{tabular}{|c|c|c|c|c|}
\hline Age group & $\begin{array}{l}\text { Swedish } \\
\text { population }\end{array}$ & $\begin{array}{c}\text { Glass- } \\
\text { workers }\end{array}$ & Farmers & Others \\
\hline \multicolumn{5}{|l|}{$45-64$ years } \\
\hline $\begin{array}{l}\text { Cases } \\
\text { Referents }\end{array}$ & $\begin{array}{r}3075 \\
129541\end{array}$ & $\begin{array}{r}6 \\
49\end{array}$ & $\begin{array}{r}9 \\
41\end{array}$ & $\begin{array}{r}4 \\
94\end{array}$ \\
\hline \multicolumn{5}{|l|}{$65-74$ years } \\
\hline $\begin{array}{l}\text { Cases } \\
\text { Referents }\end{array}$ & $\begin{array}{r}1389 \\
149623\end{array}$ & $\begin{array}{r}1 \\
40\end{array}$ & $\begin{array}{r}1 \\
86\end{array}$ & $\begin{array}{r}5 \\
106\end{array}$ \\
\hline \multicolumn{5}{|l|}{$\geq 75$ years } \\
\hline $\begin{array}{l}\text { Cases } \\
\text { Referents }\end{array}$ & $\begin{array}{r}459 \\
286892 \\
\end{array}$ & $\overline{87}$ & $\begin{array}{r}1 \\
307\end{array}$ & $\begin{array}{r}2 \\
265\end{array}$ \\
\hline \multicolumn{5}{|l|}{ Total } \\
\hline $\begin{array}{l}\text { Cases } \\
\text { Referents }\end{array}$ & $\begin{array}{r}4923 \\
566056 \\
\end{array}$ & $\begin{array}{r}7 \\
176 \\
\end{array}$ & $\begin{array}{r}11 \\
434 \\
\end{array}$ & $\begin{array}{r}11 \\
465 \\
\end{array}$ \\
\hline $\begin{array}{l}\text { Crude odds } \\
\text { ratio }\end{array}$ & 1.0 & 4.6 & 2.9 & 2.7 \\
\hline $\begin{array}{l}\text { Standardized } \\
\text { rate ratio }\end{array}$ & 1.0 & 4.0 & 6.3 & 3.0 \\
\hline $\begin{array}{l}\text { Mantel-Haenszel } \\
\text { odds ratio } \\
95 \% \text { confidence } \\
\text { interval }\end{array}$ & 1.0 & $\begin{array}{c}4.2 \\
2.0-8.6\end{array}$ & $\begin{array}{c}4.8 \\
2.7-8.5\end{array}$ & $\begin{array}{c}3.0 \\
1.7-5.4\end{array}$ \\
\hline
\end{tabular}

County Administration and the health authorities of Nybro, unpublished data). This contamination of the environment was also reflected in a survey of metal concentrations in various stream plants in an area including 9 of the 11 glass-producing parishes studied (measurements performed in the 1980s by the Geological Survey of Sweden). As an example, a map showing the distribution of zinc in the region is presented in figure 1.

The inconsistent results on brain cancer among glassworkers in various studies suggests some alternative, although rather speculative, explanations. One possi- 


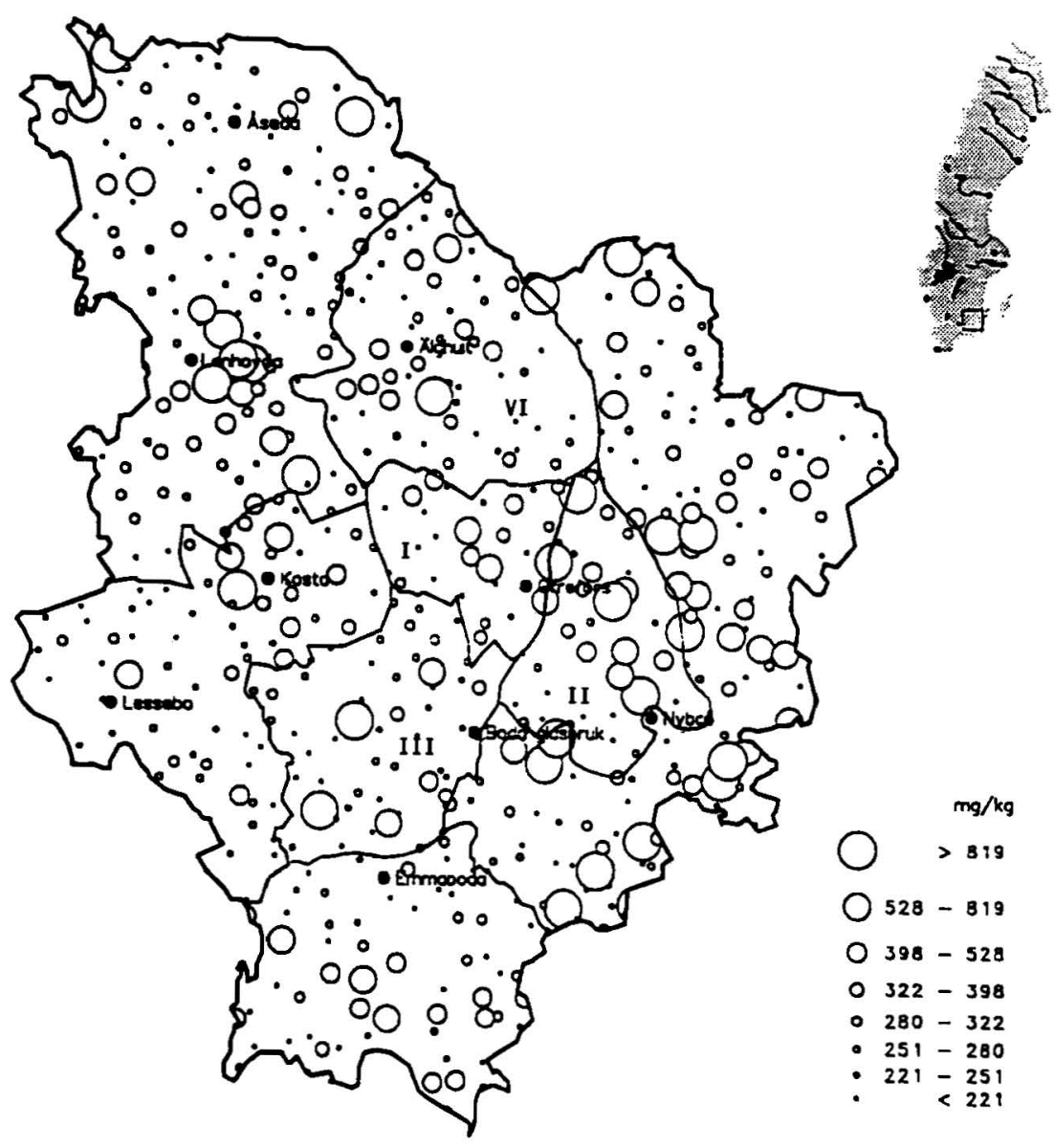

Figure 1. Zinc in stream plants from the glass-producing region of southeast Sweden and the location of the four parishes (I,II, III and VI) with the highest estimates for the standardized risk ratio (scale 1:500 000). Measurements performed by the Geological Survey of Sweden.

bility is obviously that the increased risk of brain cancer among glassworkers (1-4) simply reflects an occupational risk. Since brain cancer is a relatively rare cause of death, it is possible that some studies on glassworkers were too small to indicate an existing association. Hence, in a Swedish cohort (5), no brain tumors were found, in an Italian cohort (6) only one case appeared, and in a Finnish cohort (7) there were 5 brain tumors versus 4.1 expected among men. However, an occupational risk in this respect for glassworkers would be impossible to detect in a case-referent study using the "rest of the population" in the area as the unexposed reference if an equally high brain cancer risk would exist for some other reason for one or several other large occupational groups included in the reference population. As the glass-producing parishes in Sweden are located in a rural region, the "rest of the population" is to a large extent farmers, and an increased brain cancer risk for this occupation, as indeed indicated in this study and several other studies, would mask an existing occupational risk of brain cancer among glassworkers.
Another possibility could be that the increased brain cancer risk noted in some studies is not an occupational risk but rather reflects an environmental risk affecting a whole population. Then, register studies or any other type of study on glassworkers, using some geographically more widespread population as the unexposed reference, would falsely give the impression of an occupational risk for glassworkers due to the fact that most of them are living and working in an area with a cluster of brain cancer, whatever the specific etiology might be. For example, such a geographic cluster has also been reported to occur in a rural part of the state of Kentucky in the United States (31).

The analyses based on the Swedish Cancer-Environment Register, showing an excess brain cancer risk among glassworkers $(1,2)$, were standardized with regard to geographic region (county). Since the counties are relatively large and often include both urban and rural areas, the influence of a local cluster in a restricted part of a county, as discussed in this report, would have little impact on the brain cancer rates for the whole county. In other words, standardization by 
county would not be expected to "adjust" a false occupational risk in this respect.

Although the brain cancer cluster in the Swedish glass-producing area might have its origin in some industrial discharge from the glassworks, none of the chemicals most frequently emitted are known to be brain carcinogens in humans. An alternative etiologic factor could perhaps be the fertilizers or pesticides that are used in farming and pollute the soil and drinking water. On the other hand, this particular area cannot be thought of as clearly agricultural in character and should therefore not be expected to be more heavily polluted by chemicals used in farming.

In summary, the results of this study indicate a cluster of brain cancer in one rural region where most of the Swedish glassworks are located. The brain cancer risk suggested for Swedish glassworkers in earlier Swedish register studies seems to be part of this general cluster rather than referable to occupational exposures in glassworks. No definite etiologic explanation for this cluster can be suggested, however, which is not an uncommon result from epidemiologic studies of this kind. It can be concluded however that it is necessary to have very good knowledge of the character of the unexposed reference population in epidemiologic studies so as not to attribute a generally operating risk to an occupational exposure. This possibility can arise, particularly in register studies, when a category of workers is geographically restricted to an area where an environmental exposure or some other factor may be causing an adverse health effect in the population at large.

\section{References}

1. McLaughlin JK, Malker HSR, Blot WJ, Malker BK, Stone BJ, Weiner JA, et al. Occupational risks for intracranial gliomas in Sweden. J Natl Cancer Inst 1987; 78:253-7.

2. McLaughlin JK, Thomas TL, Stone BJ Blot WJ, Malker HSR, Weiner JA, et al. Occupational risks for meningiomas of the CNS in Sweden. J Occup Med 1987;29: 66-7.

3. Englund A, Ekman G, Zabrielski L. Occupational categories among brain tumor cases recorded in the cancer registry in Sweden. Ann NY Acad Sci 1981;381:188-96.

4. Mallin K, Rubin M, Joo E. Occupational cancer mortality in Illinois white and black males, 1979-1984, for seven cancer sites. Am J Ind Med 1989;15:699-717.

5. Wingren G, Englander V. Mortality and cancer morbidity in a cohort of Swedish glassworkers. Int Arch Occup Environ Health 1990;62:253 - 7.

6. Cordioli G, Cuoghi L, Solari PL, Berrino F, Crosignani P, Riboli E. Mortalita per tumore in una coorte di lavoratori della industria del vetro. Epidemiol prevenzione 1987;30:16-8.

7. Sankila R, Karjalainen S, Pukkala E, Oksanen H, Hakulinen T, Teppo L, et al. Cancer risk among glass factory workers: an excess of lung cancer? $\mathrm{Br} \mathbf{J}$ Ind Med 1990;47:815-8.

8. Wingren $G$, Axelson $O$. Mortality pattern in a glass producing area in SE Sweden. Br J Ind Med 1985;42: 411-4.

9. Wingren G, Axelson O. Mortality in the Swedish glassworks industry. Scand J Work Environ Health 1987; $13: 412-6$.
10. National Central Bureau of Statistics. Causes of death 1951-1982. Stockholm: Statistiska Centralbyrån, the respective years.

11. National Central Bureau of Statistics. Census of the population 1960, 1965, 1970 and 1975 . Stockholm: Statistiska Centralbyrån, the respective years.

12. Mantel M, Haenszel W. Statistical aspects of the analysis of data from retrospective studies of disease. J Natl Cancer Inst 1959;22:719-48.

13. Miettinen OS. Estimability and estimation in casereferent studies. Am J Epidemiol 1976;103:226-35.

14. Rothman KJ. Modern epidemiology. Boston/Toronto: Little, Brown and Company, 1986.

15. Thomas TL, Waxweiler RJ. Brain tumors and occupational risk factors: a review. Scand $\mathrm{J}$ Work Environ Health 1986;12:1-15.

16. Ahlbom A, Norell S, Rodvall Y, Nylander M. Dentists, dental nurses, and brain tumours. Br Med J 1986;292: 662.

17. Olin GR, Ahlbom A. The cancer mortality among Swedish chemists graduated during three decades. Environ Res 1980;22:154-61.

18. Thomas TL, Stolley PD, Stemhagen A, Fontham ETH, Bleecker ML, Stewart PA, et al. Brain tumor risk among men with electrical and electronics jobs: a case-control study. J Natl Cancer Inst 1987;79:233-8.

19. Lin RS, Dischinger PC, Conde J, Farrell KP. Occupational exposure to electromagnetic fields and the occurrence of brain tumors: an analysis of possible associations. J Occup Med 1985;27:413-9.

20. Musicco M, Filippini G, Bordo BM, Melotto A, Morello G, Berrino F. Gliomas and occupational exposure to carcinogens: case-control study. Am J Epidemiol 1982; 116:782-90.

21. Blair A, Malker H, Cantor KP, Burmeister L, Wiklund $K$. Cancer among farmers: a review. Scand J Work Environ Health 1985;11:397-407.

22. Reif JS, Pearce N, Fraser J. Occupational risks for brain cancer: a New Zealand cancer registry-based study. J Occup Med 1989;31:863-9.

23. Musicco M, Sant M, Molinari S, Filippini G, Gatta G, Berrino F. A case-control study of brain gliomas and occupational exposure to chemical carcinogens: the risk to farmers. Am J Epidemiol 1988;128:778-5.

24. Ahlbom A, Lindberg Navier I, Norell S, Olin R, Spännare B. Nonoccupational risk indicators for astrocytomas in adults. Am J Epidemiol 1986;124:334-7.

25. Choi NW, Schuman LM, Gullen WH. Epidemiology of primary central nervous system neoplasms: I. mortality from primary central nervous system neoplasms in Minnesota. Am J Epidemiol 1970;91:238-59.

26. International Agency for Research on Cancer (IARC). Some N-nitroso compounds. Lyon: IARC, 1978:191216, 227-56. (IARC monograph on the evaluation of carcinogenic risk of chemicals to humans; no 17).

27. Preston-Martin S, Yu MC, Benton B, Henderson BH. $\mathrm{N}$-nitroso compounds and childhood brain tumors: a case-control study. Cancer Res 1982;42:5240-5.

28. Seidman H, Selikoff IJ, Hammond EC. Mortality of brain tumors among asbestos insulation workers in the United States and Canada. Ann NY Acad Sci 1982; 381:160-71.

29. Rath FW, Enke H. Die wirkung peroral applizierten Zinks auf die induzierbarkeit experimenteller hirntumoren der ratte. Arch Geschwulstforsch 1984;54:201-7.

30. Oyasu R, Battifora HA, Clasen RA, McDonald JH, Hass GM. Induction of cerebral gliomas in rats with dietary lead subacetate and 2-acetylaminofluorene. Cancer Res 1970;30:1248-61.

31. Brooks WH. Geographic clustering of brain tumors in Kentucky. Cancer 1972;30:923-6.

Received for publication: 17 June 1991 